\title{
PENINGKATAN PENGETAHUAN HUKUM ANGGOTA FEDERASI SERIKAT PEKERJA KAHUTINDO KOTA TARAKAN MENGENAI PERLINDUNGAN HAK- HAK BURUH BERDASARKAN UNDANG-UNDANG NOMOR 13 TAHUN 2003 TENTANG KETENAGAKERJAAN
}

\author{
Mawardi Khairi'1), Inggit Akim¹), Sulaiman'1) \\ ${ }^{1)}$ Fakultas Hukum, Universitas Borneo Tarakan, Tarakan, Kalimantan Utara, Indonesia \\ Corresponding author : Mawardi Khairi \\ E-mail : mawardikhairi@gmail.com
}

Diterima 29 September 2020, Direvisi 05 November 2020, Disetujui 05 November 2020

\begin{abstract}
ABSTRAK
Permasalahan mitra dalam kegiatan pengabdian kepada masyarakat ini adalah minimnya pengetahuan anggota Federasi Serikat Pekerja (FSP) Kahutindo Kota Tarakan mengenai perlindungan hak-hak tenaga kerja berdasarkan Undang-Undang Nomor 13 Tahun 2003 tentang Ketenagakerjaan lebih-lebih saat pandemik Covid 19 yang mengakibatkan Pemutusan Hubungan Kerja (PHK). Solusi yang ditawarkan dalam kegiatan pengabdian kepada masyarakat ini adalah peningkatan pengetahuan hukum anggota mengenai perlindungan hak-hak buruh khususunya berdasarkan Undang-Undang Nomor 13 Tahun 2003 tentang Ketenagakerjaan sebagai payung hukum dalam bidang ketenagakerjaan. Metode pelaksanaan yang digunakan dalam kegiatan pengabdian kepada masyarakat ini adalah dengan menggunakan metode ceramah, dialog, dan diskusi dalam rangka memberikan penyuluhan hukum kepada mitra. Partisipasi mitra dalam kegiatan pengabdian kepada masyarakat ini adalah dengan menyediakan waktu, menyediakan tempat beserta fasilitas pendukung lainnya, dan menghadirkan anggotanya sebagai peserta penyuluhan hukum. Target luaran dari kegiatan pengabdian kepada masyarakat ini adalah publikasi artikel ilmiah pada jurnal nasional terakreditasi serta bagian dari implementasi Tri Dharma perguruan tinggi. Kesimpulannya adalah kegiatan pengabdian kepada masyarakat ini telah berhasil dilaksanakan dan manfaatnya dapat dirasakan langsung oleh para peserta, yaitu meningkatkan pengetahuan hukum anggota mengenai perlindungan hak-hak buruh berdasarkan Undang-Undang Nomor 13 Tahun 2003 tentang Ketenagakerjaan. Hal ini dapat dilihat dari jawaban para peserta pada kuisioner yang diberikan setelah kegiatan dilaksanakan. Dari 25 orang peserta, 87,5\% menjawab telah memahaminya. Sarannya adalah sebaiknya kegiatan dengan tema ini dilaksanakan tidak hanya kepada anggota Federasi Serikat Pekerja (FSP) Kahutindo Kota Tarakan, tetapi juga kepada buruh yang belum bergabung menjadi anggota Serikat Pekerja/Buruh.
\end{abstract}

Kata kunci: buruh; perlindungan hak; serikat pekerja.

\begin{abstract}
The problem of partners in this community service activities is the lack of knowledge of members of the Kahutindo Tarakan City Trade Union Federation (TUF) regarding the protection of labor rights based on Law Number 13 of 2003 concerning Manpower, especially during the Covid 19 pandemic which resulted in Termination of Employment (Laid off). The solution offered in this community service activity is to increase the legal knowledge of members regarding the protection of labor rights in particular based on Law Number 13 of 2003 concerning Manpower as a legal protection in the field of employment. The method of implementation used in this community service activity is to use the method of lectures, dialogues, and discussions in order to provide legal education to partners. Participation of partners in community service activities is by providing time, providing space and other supporting facilities, and presenting members as participants in legal education. The output target of this community service activity is the publication of scientific articles in accredited national journals and part of the implementation of the Tri Dharma of higher education. The conclusion is that this community service activity has been successfully implemented and the benefits can be felt directly by the participants, namely increasing members' legal knowledge regarding the protection of labor rights based on Law Number 13 of 2003 concerning Manpower. This can be seen from the answers of the participants to the questionnaire given after the activity was carried out. Of the 25 participants, $87.5 \%$ answered that they understood it. The suggestion is that activities with this theme should be carried out not only for members of the Kahutindo Tarakan City Trade Union Federation (TUF), but also for workers who have not joined the Workers / Labor Union.
\end{abstract}


Keywords : labour; protection of right; trade union.

\section{PENDAHULUAN}

Berdasarkan data BPS Kota Tarakan terdapat sekitar \pm 60.555 penduduk Kota Tarakan yang berprofesi sebagai buruh/tenaga kerja. Jumlah ini sangat banyak dan tentu membutuhkan perhatian yang serius dari pemerintah daerah.

Tabel 1. Jumlah Penduduk Berdasarkan Pekerjaan

\begin{tabular}{|c|c|c|c|c|}
\hline \multirow{2}{*}{\multicolumn{2}{|c|}{$\begin{array}{l}\text { Status Pekerjaan Utama } \\
\text { Main Employment Status }\end{array}$}} & \multicolumn{3}{|c|}{ Jenis Kelamin/Sex } \\
\hline & & $\begin{array}{l}\text { Laki-laki } \\
\text { Male }\end{array}$ & $\begin{array}{l}\text { Perempuan } \\
\text { Female }\end{array}$ & $\begin{array}{c}\text { Jumlah } \\
\text { Total }\end{array}$ \\
\hline & (1) & (2) & (3) & (4) \\
\hline 1. & Berusaha Sendiri & 11776 & 5478 & 17254 \\
\hline 2. & $\begin{array}{l}\text { Berusaha dibantu buruh } \\
\text { tidak tetap/tak dibayar }\end{array}$ & 5268 & 705 & 5973 \\
\hline 3. & $\begin{array}{l}\text { Berusaha dibantu buruh } \\
\text { tetap/ buruh dibayar }\end{array}$ & 6413 & 799 & 7212 \\
\hline 4. & Buruh/Karyawan/Pegawai & 42140 & 18415 & 60.555 \\
\hline 5. & Pekerja bebas & 1968 & 428 & 2396 \\
\hline 6. & Keluarga/tidak & 2349 & 2788 & 5137 \\
\hline & Jumlah/Total & 69.914 & 28.613 & 98.527 \\
\hline
\end{tabular}

Pada tahun 2016, jumlah perusahaan kecil dan menengah di Kota Tarakan adalah 530 perusahaan dengan jumlah tenaga kerja sebanyak 2.271 orang. Bila dilihat berdasarkan klasifikasi industri, dari 530 perusahaan kecil dan menengah yang ada di Kota Tarakan pada tahun 2016, 9,62 persen adalah perusahaan kecil dan menengah untuk klasifikasi industri sandang; 6,98 persen adalah mebel; 18,49 persen adalah pangan; 13,02 persen adalah kimia dan bahan bangunan; 6,04 persen adalah hasil hutan; 41,70 persen adalah logam dan elektronika; serta 4,15 persen adalah kerajinan.

Pada tahun 2016, terdapat 705 perusahaan di Kota Tarakan yang tercatat badan hukumnya di Dinas Penanaman Modal dan Pelayanan Terpadu Satu Pintu Kota Tarakan. Dari 705 perusahaan tersebut, bila dirinci menurut tipe badan hukumnya, maka
196 adalah perusahaan dengan badan hukum perseroan terbatas, 244 firma, 8 perusahaan dengan tipe badan hukum adalah koperasi, 256 $\mathrm{PO}$, dan 1 perusahaan dengan tipe badan hukum BUL.

Tahun 2016, terdapat 146 koperasi di Kota Tarakan yang tersebar di masing-masing kecamatan yang ada di Kota Tarakan. 34,25 persen koperasi tersebut (50 koperasi) berada di Kecamatan Tarakan Tengah, 33,56 persen (49 koperasi) berada di Kecamatan Tarakan Barat, 21,23 persen (31 koperasi) di Kecamatan Tarakan Timur, dan 10,96 persen berada di Kecamatan Tarakan Utara.

Jumlah Perusahaan Menurut Bentuk Badan Hukum di Kota Tarakan, 2012-2016

Tabel 2. Jumlah Perusahaan Menurut Bentuk Badan Hukum di Kota Tarakan

\begin{tabular}{llllll}
\hline \hline \multicolumn{1}{r}{ Tipe Badan Hukum } & 2012 & 2013 & 2014 & 2015 & 2016 \\
\hline \multicolumn{1}{c}{$(1)$} & $(2)$ & $(3)$ & $(4)$ & $(6)$ & $(7)$ \\
\hline Perseroan terbatas & 133 & - & 150 & 205 & 196 \\
CV/Firma & 266 & - & 350 & 282 & 244 \\
Koperasi & 16 & - & 5 & 16 & 8 \\
FA & 0 & - & 0 & 1 & 0 \\
PO & 262 & - & 187 & 380 & 256 \\
BUL & 3 & - & 4 & 4 & 1 \\
\hline Jumlah & 680 & - & 696 & 888 & 705 \\
\hline \hline
\end{tabular}

Sumber: Dinas Penanaman Modal dan Pelayanan Terpadu Satu Pintu Kota Tarakan 
Berikut ini jumlah perusahaan dan tenaga kerja yang ada di Kota Tarakan Tahun 2017 sebagai berikut:

Tabel 3. Jumlah perusahaan dan tenaga kerja yang ada di Kota Tarakan Tahun 2017

\begin{tabular}{lll}
\hline \hline Klasifikasi & Jml & Jumlah \\
Perusahaan & Perusahaan & Tenaga Kerja
\end{tabular}

(2)

(3)

\begin{tabular}{lll}
\hline BESAR & 46 & 15.072 \\
SEDANG & 38 & 2.616 \\
KECIL & 209 & 3.253 \\
& & \\
\hline Jumlah & 293 & 20.941 \\
\hline \hline
\end{tabular}

\section{Sumber: Dinas Perindustrian dan Tenaga Kerja Kota Tarakan}

Berdasarkan data tersebut tenaga kerja berhak mendapatkan perlindungan hakhaknya sebagai pekerja. Undang-Undang Dasar Negara Republik Indonesia Tahun 1945 mengamanatkan bahwa tiap-tiap warga negara berhak atas pekerjaan dan penghidupan yang layak bagi kemanusiaan. Sejalan dengan itu, Undang-Undang Nomor 13 Tahun 2003 tentang Ketenagakerjaan menegaskan bahwa setiap tenaga kerja memiliki kesempatan yang sama tanpa diskriminasi untuk memperoleh pekerjaan. Hal ini juga di dukung pada riset kami sebelumnya tentang Tanggung Jawab Perusahaan Dalam Pemenuhan Jaminan Sosial Ketenagakerjaan Di Kota Tarakan,dimana hasil penelitian menggambarkan bahwa hanya $9 \%$ perusahaan di Kota Tarakan sudah mendaptarkan perusahaan dan tenaga kerjanya dalam program BPJS Ketenagakerjaan sesuai ketentuan pasal 15 ayat 1 Undang-Undang Nomor 24 Tahun 2011 tentang Badan Penyelenggaran Jaminan Sosial dan $91 \%$ perusahaan belum mendaptarkan perusahaan dan tenaga kerjanya pada BPJS Ketenagakerjaan. Oleh karena itu, perlindungan terhadap hak-hak tenaga kerja merupakan tanggung jawab negara. Selain itu, perlindungan terhadap hak-hak tenaga kerja perlu terus disosialisasikan mengingat tidak semua tenaga kerja yang mengetahui hukum, khususnya UndangUndang Nomor 13 Tahun 2003 tentang Ketenagakerjaan.

\section{METODE}

Metode pelaksanaan yang digunakan dalam kegiatan pengabdian kepada masyarakat ini adalah dengan menggunakan metode ceramah, dialog, dan diskusi dalam rangka penyuluhan hukum tentang peningkatan pengetahuan hukum anggota Federasi Serikat Pekerja (FSP) Kahutindo Kota Tarakan mengenai perlindungan hak-hak buruh berdasarkan Undang-Undang Nomor 13 Tahun 2003 tentang Ketenagakerjaan.

Metode pendekatan yang dilakukan untuk menyelesaikan permasalahan mitra dalam kegiatan pengabdian kepada masyarakat ini adalah dengan melakukan kunjungan awal ke sekretariat Federasi Serikat Pekerja (FSP) Kahutindo Kota Tarakan guna menggali beberapa informasi mengenai kondisi anggotanya. Setelah itu, melakukan dialog dengan beberapa orang pengurus Federasi Serikat Pekerja (FSP) Kahutindo Kota Tarakan guna mencari tahu permasalahan yang sedang dihadapinya.

Partisipasi mitra dalam kegiatan pengabdian kepada masyarakat ini adalah Ketua Federasi Serikat Pekerja (FSP) Kahutindo Kota Tarakan sebagai penanggung jawab kegiatan berkontribusi menyediakan tempat dan fasilitas penunjang untuk pelaksanaan kegiatan serta menghadirkan anggota Federasi Serikat Pekerja (FSP) Kahutindo Kota Tarakan sebagai peserta kegiatan penyuluhan hukum tentang peningkatan pengetahuan anggota Federasi Serikat Pekerja (FSP) Kahutindo Kota Tarakan mengenai perlindungan hak-hak tenaga kerja berdasarkan Undang-Undang Nomor 13 Tahun 2003 tentang Ketenagakerjaan.

Evaluasi pelaksanaan kegiatan pengabdian kepada masyarakat ini dilakukan dengan membagikan kuisioner sebelum dan sesudah kegiatan dilaksanakan untuk mengukur tingkat pengetahuan para peserta. Keberhasilan pelaksanaan kegiatan pengabdian kepada masyarakat ini diukur dari antusias para peserta yang mengikuti kegiatan dan banyaknya pertanyaan yang diajukan oleh para peserta. Bahkan, salah satu peserta meminta agar kegiatan ini diadakan kembali bulan depan.

\section{PEMBAHASAN}

Kegiatan pengabdian kepada masyarakat ini dilaksanakan pada hari Minggu tanggal 12 September 2020 dimulai pukul 08.00 WITA sampai dengan selesai di sekretariat Federasi Serikat Pekerja (FSP) Kahutindo Kota Tarakan yang beralamat di JI.Mulawarman No.27 Kota Tarakan. Kegiatan pengabdian kepada masyarakat ini dihadiri sebanyak 25 
(dua puluh lima) orang peserta. Pelaksanaan kegiatan pengabdian kepada masyarakat ini berjalan dengan lancar karena judul yang diangkat sesuai dengan yang permasalahan mitra dan kebutuhan para peserta.

Sikap khalayak sasaran selama pelaksanaan kegiatan pengabdian kepada masyarakat ini adalah baik dan antusias dalam memperhatikan materi yang dipaparkan oleh tim pelaksana. Hal ini didukung oleh Ketua Federasi Serikat Pekerja (FSP) Kahutindo Kota Tarakan yang memfasilitasi kegiatan dengan menyediakan waktu, tempat, dan fasilitas pendukung lainnya.

Selain meningkatkan pengetahuan anggota K-SPSI Kahutindo Kota Tarakan mengenai perlindungan hak-hak tenaga kerja berdasarkan Undang-Undang Nomor 13 Tahun 2003 tentang Ketenagakerjaan, hasil fisik yang bermanfaat bagi para peserta adalah memperoleh materi yang diberikan oleh tim pelaksana dalam bentuk fotokopi hand out materi.

Untuk mengetahui sejauh mana tingkat pengetahuan para peserta mengenai materi yang akan disampaikan, maka sebelum pelaksanaan kegiatan, tim pelaksana membagikan kuisioner untuk langsung diisi oleh para peserta. Selanjutnya, untuk mengatahui keberhasilan dari pelaksanaan kegiatan pengabdian kepada masyarakat ini, maka tim pelaksana kembali membagikan kuisioner kepada para peserta setelah kegiatan dilaksanakan.

Pelaksanaan kegiatan pengabdian kepada masyarakat ini dapat dikatakan telah berhasil dilaksanakan dan manfaatnya dapat dirasakan langsung oleh para peserta, yaitu meningkatkan pengetahuan anggota Federasi Serikat Pekerja (FSP) Kahutindo Kota Tarakan mengenai perlindungan hak-hak tenaga kerja berdasarkan Undang-Undang Nomor 13 Tahun 2003 tentang Ketenagakerjaan. Hal ini dapat dilihat dari jawaban para peserta pada kuisioner yang diberikan sebelum dan setelah kegiatan dilaksanakan. Sebelum kegiatan dilaksanakan, dari 25 orang peserta, hanya $12,5 \%$ yang jawabannya telah mengetahui. Setelah kegiatan dilaksanakan, sebanyak 87,5\% peserta menjawab telah mengetahuinya.

Pada kegiatan pengabdian kepada masyarakat ini, tim pelaksana memaparkan materi mengenai perlindungan hak-hak tenaga kerja kontrak berdasarkan Undang-Undang Nomor 13 Tahun 2003 tentang Ketenagakerjaan. Menurut undang-undang tersebut, yang menjadi hak-hak bagi tenaga kerja kontrak adalah sebagai berikut:

Perlakuan yang sama tanpa diskriminasi (Pasal 6).
1. Pelatihan kerja (Pasal 12 Ayat 3).

2. Penempatan kerja (Pasal 31).

3. Tidak ada masa percobaan (Pasal 58 Ayat 1).

4. Waktu kerja (Pasal 77 Ayat 2).

5. Waktu kerja lembur (Pasal 78 Ayat 1).

6. Upah kerja lembur (Pasal 78 Ayat 2).

7. Waktu istirahat dan cuti (Pasal 79 Ayat 2).

8. Waktu untuk beribadah wajib (Pasal 80).

9. Tenaga kerja perempuan yang haid (Pasal 81 Ayat 1).

10. Tenaga kerja perempuan yang melahirkan (Pasal 82).

11. Tenaga kerja perempuan yang menyusui (Pasal 83).

12. Perlindungan atas keselamatan dan kesehatan kerja (Pasal 86 Ayat 1).

13. Penghasilan yang layak (Pasal 88 Ayat 1).

14. Upah minimum (Pasal 90 Ayat 1).

15. Jaminan sosial tenaga kerja (Pasal 99 Ayat 1).

16. Hak uang pesangon (Pasal 156 Ayat 2).

17. Hak uang penghargaan masa kerja (Pasal 156 Ayat 3).

Kegiatan pengabdian kepada masyarakat ini ditanggapi secara positif oleh para peserta. Tanggapan positif itu dapat dilihat dari adanya respon berupa pertanyaan dari salah seorang peserta setelah tim pelaksana memaparkan materi, yaitu peserta yang bernama Rudi mengajukan pertanyaan "Bagaimana cara melaporkan apabila ada perusahaan yang yang tidak mendaptarkan pekerja sebagai anggota BPJS Ketenagakerjaan dan tidak membayarkan iuran BPJS Ketenagakerjakaan padahal sudah di bayar oleh buruh? Apakah ada sanksinya untuk perusahaan tersebut?

Perlindungan terhadap hak pekerja bersumber pada Pasal 27 ayat (2) UUD 1945, yaitu tiap-tiap warga negara berhak atas pekerjaan dan penghidupan yang layak bagi kemanusiaan. Selain itu jaminan perlindungan atas pekerjaan dituangkan pula dalam dalam ketentuan Pasal 28 D ayat (1) UUD 1945, yaitu Setiap orang berhak atas pengakuan, jaminan, perlindungan dan kepastian hukum yang adil serta perlakuan yang sama dihadapan hukum. Pasal 28 ayat (2), yaitu setiap orang berhak untuk bekerja serta mendapat imbalan dan perlakuan yang adil dan layak dalam hubungan kerja.

Ketentuan tersebut menunjukan bahwa di Indonesia hak untuk bekerja telah memperoleh tempat penting dan dilindungi oleh UUD 1945. UUD 1945 Pasal 28 H (amandemen 
kedua) menyatakan bahwa setiap orang berhak atas jaminan sosial yang memungkinkan pengembangan dirinya secara utuh sebagaimana manusia yang bermartabat dan Pasal 34 ayat 2 (amandemen keempat) menyatakan bahwa negara mengembangkan sistem jaminan sosial bagi seluruh rakyat dan memberdayakan masyarakat yang lemah dan tidak mampu sesuai dengan martabat kemanusiaan.

Undang - Undang Nomor 13 Tahun 2003 tentang Ketenagakerjaan selanjutnya disingkat UU Ketenagakerjaan. Berdasarkan ketentuan Pasal 99 ayat 1 menyebutkan bahwa setiap pekerja/buruh dan keluarganya berhak untuk memperoleh jaminan social tenaga kerja dan pada ayat 2 menyebutkan jaminan sosial tenaga kerja sebagaimana dimaksud dalam ayat (1) dilaksanakan sesuai dengan peraturan perundang-undangan yang berlaku. Program jaminan sosial ketenagakerjaan ditujukan dalam rangka memberikan kepastian keberlangsungan penghasilan pekerja sebagai pengganti sebagian atau keseluruhan penghasilan yang hilang yang di akibatkan terjadinya kecelakaan kerja.

Pemenuhan hak-hak pekerja haruslah sesuai dengan peraturan yang berlaku dan pengusaha tidak dapat melakukan kesewenang-wenangan terhadap pekerjanya. Pemenuhan hak tersebut antara lain tentang upah yang harus sesuai dengan upah minimum daerah setempat, tentang jaminan sosial ketenagakerjaan yang telah diatur dibeberapa peraturan perundang-undangan, tunjangantunjangan dan pemenuhan hakhak pekerja lain yang terdapat dalam UU Ketenagakerjaan. Program jaminan social ketenagakerjaan merupakan hak setiap tenaga kerja, baik dalam hubungan kerja maupun tenaga kerja luar hubungan kerja.

Maka untuk memenuhi hak dari pekerja pemerintah melalui Program jaminan sosial ketenagakerjaan mewajibankan setiap perusahaan (pemberi kerja) sebagaimana di atur dalam Pasal 15 ayat 1 UU BPJS yang menyatakan bahwa Pemberi Kerja secara bertahap wajib mendaftarkan dirinya dan Pekerjanya sebagai Peserta kepada BPJS sesuai dengan program Jaminan Sosial yang diikuti. Pasal 15 ayat (1) UU BPJS telah mengatur tentang kewajiban pemberi kerja secara bertahap wajib mendaftarkan dirinya dan Pekerjanya sebagai Peserta kepada BPJS sesuai dengan program jaminan sosial yang diikuti. Ketentuan ini dipertegas kembali dalam Pasal 3 Ayat 1 Peraturan Pemerintah Republik Indonesia Nomor 86 Tahun 2013 tentang Tata Cara Pengenaan Sanksi Administratif Kepada Pemberi Kerja Selain Penyelenggara Negara dan Setiap Orang, Selain Pemberi Kerja, Pekerja, dan Penerima Bantuan luran Dalam Penyelenggaraan Jaminan Sosial selanjutnya disingkat PP 86 Tahun 2013 menyatakan bahwa pemberi kerja selain penyelenggara negara wajib:

Mendaftarkan dirinya dan pekerjanya sebagai peserta kepada BPJS secara bertahap sesuai dengan program jaminan sosial yang diikutinya; dan

Memberikan data dirinya dan pekerjanya berikut anggota keluarganya kepada BPJS secara lengkap dan benar.

Kewajiban pemberi kerja mendaftarkan pekerjanya sebagai peserta BPJS Ketenagakerjaan. Setiap pekerja yang bekerja dan menerima upah wajib diikut sertakan program BPJS oleh si pemberi kerja tanpa ada batasan mengenai jumlah pekerjanya. pekerja yang dimaksud adalah setiap orang yang bekerja menerima gaji, upah atau imbalan dalam bentuk lain (pasal 1 angka 11 UU SJSN) dan pemberi kerja adalah orang perseorangan, pengusaha, badan hukum, atau badan-badan lainnya yang mempekerjakan tenaga kerja atau penyelenggara negara yang mempekerjakan pegawai negeri dengan membayar gaji, upah, atau imbalan dalam bentuk lainnya (pasal 1 angka 12 UU SJSN).

Jadi, perusahaan dalam bentuk persekutuan dengan karyawan di atas 20 orang itu termasuk pemberi kerja yang wajib mendaftarkan pekerjanya sebagai peserta BPJS Ketenagakerjaan. Pasal 14 UU BPJS pemberi kerja secara bertahap wajib mendaftarkan dirinya dan pekerjanya sebagai peserta kepada BPJS, sesuai dengan program jaminan sosial yang diikuti dan pekerja berhak untuk mendaftarkan diri sebagai peserta program jaminan sosial atas tanggungan pemberi kerja apabila pemberi kerja telah nyata-nyata tidak mendaftarkan pekerjanya pada BPJS.

Pasal 15 ayat (1) UU BPJS jo. Putusan Mahkamah Agung Nomor 82/PUU-X/2012 tentang persyaratan dan tata cara kepesertaan dalam program jaminan sosial ini diatur Peraturan Pemerintah Nomor 84 Tahun 2013 tentang Perubahan Kesembilan Atas Peraturan Pemerintah Nommor 14 tahun 1993 tentang Penyelenggaraan Program Jaminan Sosial tenaga Kerja selanjutnya disingkat PP No. 84 Tahun 2013. Dalam PP No. 84 Tahun 2013 ini antara lain disebutkan bahwa pengusaha yang mempekerjakan tenaga kerja sebanyak 10 orang atau lebih, atau membayar upah paling sedikit $R p 1$ juta sebulan, wajib mengikutsertakan tenaga kerjanya dalam program jaminan sosial tenaga kerja (Pasal 2 ayat (3) PP No. 84 Tahun 2013. 
Adapun sanksi bagi perusahaan jika perusahaan selain penyelenggara negara tidak melaksanakan kewajiban mendaftarkan pekerjanya sebagai peserta kepada BPJS adalah berupa sanksi administrasi. Selain sanksi administrasi sanksi pidana juga dapat di jatuhkan kepada pemberi kerja/pengusaha. UU Badan Penyelenggara Jaminan Sosial (BPJS) yang berlaku 1 Januari 2014 mewajibkan peserta membayar iuran dalam jumlah tertentu. Bila tidak

membayarkan iuran wajib itu, dapat di kenakan sanksi pidana. Pembayar iuran atau premi BPJS menurut Pasal 19 UU tersebut adalah pemberi kerja, peserta yang bukan pekerja dan bukan penerima bantuan iuran wajib, dan pemerintah. Yang dimaksud pemberi kerja adalah orang perseorangan, pengusaha, badan hukum, atau badan lainnya yang mempekerjakan tenaga kerja atau penyelenggara negara yang mempekerjakan pegawai negeri dengan membayar gaji, upah, atau imbalan dalam bentuk lainnya. Berikut bunyi pasal pembayar iuran yang tercantum dalam Pasal 19 yang menyatakan:

Pemberi Kerja wajib memungut luran yang menjadi beban Peserta dari Pekerjanya dan menyetorkannya kepada BPJS.

Pemberi Kerja wajib membayar dan menyetor luran yang menjadi tanggung jawabnya kepada BPJS.

Peserta yang bukan Pekerja dan bukan penerima Bantuan luran wajib membayar dan menyetor luran yang menjadi tanggung jawabnya kepada BPJS.

Pemerintah membayar dan menyetor luran untuk penerima Bantuan luran kepada BPJS

Ketentuan lebih lanjut mengenai:

besaran dan tata cara pembayaran luran program jaminan Kesehatan diatur dalam Peraturan Presiden; dan

besaran dan tata cara pembayaran luran selain program jaminan kesehatan diatur dalam Peraturan Pemerintah.

Ketentuan sanksi dalam UU BPJS dikenakan hanya pada pemberi kerja saja jika lalai membayar iuran BPJS yakni pidana maksimal 8 tahun penjara atau denda maksimal Rp 1 miliar,sebagaimana tercantum dalam Pasal 55 yang menyatakan bahwa Pemberi Kerja yang melanggar ketentuan sebagaimana dimaksud dalam Pasal 19 ayat (1) atau ayat (2) dipidana dengan pidana penjara paling lama 8 (delapan) tahun atau pidana denda paling banyak Rp1.000.000.000,00 (satu miliar rupiah)

Selain itu, dalam Tri Dharma perguruan tinggi, salah satu kewajiban seorang dosen adalah melaksanakan pengabdian kepada masyarakat. Oleh karena itu, kegiatan penyuluhan hukum dengan judul Peningkatan Pengetahuan Hukum Anggota Federasi Serikat Pekerja (FSP) Kahutindo Kota Tarakan Mengenai Perlindungan Hak-Hak Buruh Berdasarkan Undang-Undang Nomor 13 Tahun 2003,ini merupakan salah satu bentuk pengabdian kepada masyarakat berupa penyuluhan hukum yang dilaksanakan oleh tim pelaksana dari Fakultas Hukum Universitas Borneo Tarakan.

\section{SIMPULAN DAN SARAN Simpulan}

Permasalahan mitra dalam kegiatan pengabdian kepada masyarakat ini adalah minimnya pengetahuan anggota Federasi Serikat Pekerja (FSP) Kahutindo Kota Tarakan mengenai perlindungan hak-hak tenaga kerja berdasarkan Undang-Undang Nomor 13 Tahun 2003 tentang Ketenagakerjaan khususnya tentang tertunggaknya iuran BPJS Ketenagakerjaan. Pelaksanaan kegiatan pengabdian kepada masyarakat ini dapat dikatakan telah berhasil dilaksanakan dan manfaatnya dapat dirasakan langsung oleh para peserta, yaitu meningkatkan pengetahuan Federasi Serikat Pekerja (FSP) Kahutindo Kota Tarakan mengenai perlindungan hak-hak tenaga kerja kontrak berdasarkan UndangUndang Nomor 13 Tahun 2003 tentang Ketenagakerjaan. Hal ini dapat dilihat dari jawaban para peserta pada kuisioner yang diberikan sebelum dan setelah kegiatan dilaksanakan. Sebelum kegiatan dilaksanakan, dari 25 orang peserta, hanya $12,5 \%$ yang jawabannya telah mengetahui. Setelah kegiatan dilaksanakan, sebanyak $87,5 \%$ peserta menjawab telah mengetahuinya.

\section{Saran}

Pengabdian kepada masyarakat dengan tema mengenai perlindungan hak-hak tenaga kerja ini penting untuk terus dilaksanakan karena merupakan permasalahan yang selalu dihadapi oleh tenaga kerja. Sebaiknya kegiatan dengan tema ini dilaksanakan tidak hanya kepada anggota Federasi Serikat Pekerja (FSP) Kahutindo Kota Tarakan tetapi juga kepada tenaga kerja yang belum bergabung menjadi anggota Federasi Serikat Pekerja (FSP) Kahutindo Kota Tarakan maupun organisasi serikat pekerja sejenis lainnya.

\section{DAFTAR RUJUKAN}

Abdul, K. (2003). Pengantar Hukum Ketenagakerjaan Indonesia. Citra Aditya Bakti.

Aris, Ananta. (1996). Liberalisasi Ekspor dan Impor Tenaga Kerja Suatu Pemikiran 
Awal, Pusat Penelitian Kependudukan UGM. Yogyakarta.

Asikin, Z. (2002). Dasar-Dasar Hukum Perburuhan. Grafindo Persada.

Gouw, G. Siong. (1996). Pengertian Tentang Negara Hukum, KengPo. Jakarta.

Hardijan, Rusli. (2003). Hukum Ketenagakerjaan. Ghalia Indonesia, Jakarta.

Irfan, Fachrudin. (2004). Pengawasan Peradilan Administrasi terhadap Tindakan Pemerintah, Cetakan I, Alumni, Bandung.

Lalu, Husni. (2014). Pengantar Hukum Ketenagakerjaan, Ed-Revisi, Raja Grafindo Persada. Jakarta.

Latif, A. (2005). Hukum dan Peraturan Kebijaksanaan (Beleidsregel) pada Pemerinthan Daerah. UII Press.

Peraturan Pemerintah Nomor 86 Tahun 2013 tentang Tata Cara Pengenaan Sanksi Administratif Kepada Pemberi Kerja Selain Penyelenggara Negara dan Setiap Orang, Selain Pemberi Kerja, Pekerja, dan Penerima Bantuan Iuran Dalam Penyelenggaraan Jaminan Sosial, (2013).

Philipus, M. Hadjon. (1994). Pengkajian IImu Hukum Dogmatik (Normatif), Fakultas Hukum Universitas Airlangga. Surabaya.

Salim, HS. (2001). Pengantar Hukum Perdata Tertulis (BW), Bandung.

Undang - Undang Nomor 13 Tahun 2003 Tentang Ketenagakerjaan, (2003).

Undang - Undang Nomor 40 Tahun 2004 Tentang Sistem Jaminan Sosial Nasional, (2004).

Undang - Undang Nomor 24 Tahun 2011 Tentang Badan Penyelenggara Jaminan Sosial, (2011).

Zaeni, Asyhadie. (2008). Hukum Kerja (Hukum Ketenagakerjaan Bidang Hubungan Kerja), edisi revisi2, PT.RajaGrafindo Persada. Jakarta. 